\title{
Editorial: Trust: The Limits of Human Moral
}

\author{
Panagiotis Mitkidis ${ }^{1,2 *}$, Michaela Porubanova ${ }^{3,4,5}$ and Andreas Roepstorff ${ }^{6,7}$ \\ ${ }^{1}$ Department of Management, School of Business and Social Science, Aarhus University, Aarhus, Denmark, ${ }^{2}$ Center for \\ Advanced Hindsight, Social Science Research Institute, Duke University, Durham, NC, USA, ${ }^{3}$ Department of Psychology, \\ Farmingdale State College, New York, NY, USA, ${ }^{4}$ HUME Lab, Masaryk University, Brno, Czechia, ${ }^{5}$ New School for Social \\ Research, New York, NY, USA, ${ }^{6}$ Interacting Minds Centre, Aarhus University, Aarhus, Denmark, ${ }^{7}$ Department of Clinical \\ Medicine, Center for Functionally Integrative Neuroscience, Aarhus University, Aarhus, Denmark
}

Keywords: trust, cooperation, expectations, interaction, cognition, morality

\section{Editorial on the Research Topic}

\section{Trust: The Limits of Human Moral}

The role of trust in human interaction has been a long-standing question in social sciences, and the interest has proliferated over the last few decades (Gambetta, 2000; Fukuyama, 1995; Dirks and Ferrin, 2001; Fehr, 2009). The majority of scientists agree that trust is a necessary ingredient for almost all functioning human interactions, from love and friendship to economic prosperity and the emergence of large-scale organizations (Slovic, 1993; Mayer et al., 1995; Fehr and Gächter, 1998; Hetherington, 1998; Fehr and Rockenbach, 2003). Research in psychology, anthropology, neuroscience, and economics has made tremendous advancements in identifying the psychological factors that promote trust behavior among humans (Adolphs, 2002; Delgado et al., 2005; KingCasas et al., 2005; Kosfeld et al., 2005; Williams and Bargh, 2008; Sellaro et al., 2014; Mitkidis et al., 2015). These findings have inspired the development of interventions that promote effective interactions and discourage free-riding (Ba et al., 2003; Ariely, 2009, 2016).

Trust is a public good and is based on social intelligence; "... a kind of intelligence that allows individuals to assess the degree of risk they may face in social situations when confronted with the possibility of interacting with strangers who might be the path to new and beneficial outcomes." (Cook, 2001, xiii). Based on the above, it is obvious that trust is a risky endeavor given the uncertainty one may face when interacting with others ${ }^{1}$.

The first section of this special topic issue aspires to examine how people actually behave in situations of trust and to highlight the psychological and situational factors that foster trust. The second section aims to unravel some of the socio-cognitive and evolutionary mechanisms underlying trust and morality.

\section{HOW HUMAN INTERACTION IMPROVES OR DECREASES TRUST}

How we can create and maintain positive human interaction has been both a historical question of the social sciences and a rapidly growing research topic (Lewis and Weigert, 1985; Rand et al., 2009; Wallot et al., 2016). Given how beneficial trust is in human relationships, it seems relevant to examine the factors that may increase or decrease trusting behavior and subsequently enhance cooperation. Trust motivation has been investigated by numerous studies (Yamagishi and Yamagishi, 1994; Kramer, 1999; Hardin, 2001; Mitkidis et al., 2013), illustrating that positive interactions with an individual or a group lead to higher trustworthiness and subsequently

\footnotetext{
${ }^{1}$ Maybe this is why Bob Dylan is so pessimistic when it comes to trust Dylan (1985).
} 
cooperation (Fehr and Fischbacher, 2004; Rand et al., 2009). In the real world, as well as in experiments involving social dilemmas, people do not always act in a purely selfish manner but rather display a variety of prosocial behaviors (Ostrom and Walker, 1991; Fehr and Gächter, 2000; Ariely, 2008). This raises the question: under which circumstances do we trust each other?

In this special issue on trust, several studies explored how the amount and the type of contact affects trusting behavior. Aarøe et al. demonstrate a negative association between individual's pathogen avoidance and social trust level. Håkonsson et al. examine both the selfish and trust behavior in organizations where communication is predominantly executed via different types of media. The authors generate hypotheses about how the media increase trust behavior in distributed teams. Michael et al. theorize that a necessary precursor to trusting behavior is a feeling of a sense of commitment. Andrighetto et al. investigate the factors other than fear of punishment, reputation, and others' expectations that can motivate trust. Their results propose that in the absence of the abovementioned incentives, normative expectations promote risky behaviors as trust is. Trust is therefore analogous to answering a very simple question: Can I trust you to do something? This question is a very practical one and reveals the essential mechanism behind interpersonal trust: the ability to predict actions of other people (Gambetta, 2000). Tackling this line of research, Hommel, and Colzato hypothesize that the degree of trust among individuals is largely determined by the degree of interpersonal similarity.

\section{SOCIAL COGNITION OF TRUST}

It has become widely accepted that people have cooperative preferences when taking into consideration the well-being of the group (Hamilton and Axelrod, 1981; Axelrod, 1984, 2006; Burton-Chellew and West, 2013; Rand and Nowak, 2013). Participating in cooperative tasks necessarily depends upon trust for the accomplishment of collective goals (Bratman, 1992; Cannon-Bowers and Salas, 2001). Empirically, trust has been associated with higher economic growth, the emergence of largescale organizations, and lower levels of cheating in small-scale groups and corruption on the aggregate level of larger scale societies (Arrow, 1972; Putnam, 1993; Fukuyama, 1995; Knack and Keefer, 1997; Barr, 2003; Guiso et al., 2006; Johnson and Mislin, 2011). Contrary to the benefits of trust, its pitfalls are related to immoral behavior and potential corruption (Weisel and Shalvi, 2015).

\section{REFERENCES}

Adolphs, R. (2002). Trust in the brain. Nat. Neurosci. 5, 192-193. doi: $10.1038 / \mathrm{nn} 0302-192$

Ariely, D. (2008). Predictably Irrational. New York, NY: HarperCollins.

Ariely, D. (2009). The end of rational economics. Harv. Bus. Rev. 87, 78-84.

Ariely, D. (2016). Available online at: http://people.duke.edu/ dandan/webfiles/ PapersOther/DialogueCoverlet.ariely.pdf

Arrow, K. J. (1972). Gifts and exchanges. Philos. Public Aff. 1, 343-362.
Several works examine the link between trust and morality and the mechanisms underlying those behaviors. Collins et al. suggest that trust is a cognitive mechanism supplementary to other mechanisms within the cognitive system. Hochman et al. suggest that although people have an egoistic side, considerations that require some kind of social exchange and negotiation may dominate the self-interested instincts. Espín et al. argue that since people can stand on both sides of the trust game, namely act as both trustors and trustees, social preferences may considerably differ and extent from self-interest to efficiency and performance considerations. Tan et al. demonstrate that general system justification, a motivation to sustain the status quo of the society, is negatively associated with both corruption perception and corruption intention and that institutional trust plays a mediating role in these relations. Konis et al. provide insights into how a perception of immorality of an act differs for multiple victims in comparison to a single individual. Finally, Heintz et al. consider trust from an evolutionary perspective and hypothesize that human cognition evolved mainly for dealing with social life and despite its risky nature, trust may be advantageous.

\section{CONCLUSION: THE LIMITS OF HUMAN MORAL}

In the course of daily life, people routinely engage in social exchanges that involve some level of trust. Studies published as a part of the current research topic suggest that individuals do not automatically adopt trusting and moral behavior in human interactions, but that those behaviors are determined by and modulated by a plethora of cognitive, psychological, situational, and contextual factors. We believe that research published within the special topic significantly contributes to understanding of trust and we encourage further research both on the brighter and darker sides of trust.

\section{AUTHOR CONTRIBUTIONS}

All authors listed, have made substantial, direct and intellectual contribution to the work, and approved it for publication.

\section{ACKNOWLEDGMENTS}

The guest editors would like to personally thank all the authors and reviewers who contributed their time and effort to this research topic. We also want to thank the help of Frontiers Editorial Office for all the help.

Axelrod, R. (1984). The Evolution of Cooperation. New York, NY: Basic Books Axelrod, R. M. (2006). The Evolution of Cooperation. New York, NY: Basic books. Ba, S., Whinston, A. B., and Zhang, H. (2003). Building trust in online auction markets through an economic incentive mechanism. Decis. Support Syst. 35, 273-286. doi: 10.1016/S0167-9236(02)0 0074-X

Barr, A. (2003). Trust and expected trustworthiness: experimental evidence from Zimbabwean villages. Econ. J. 113, 614-630. doi: 10.1111/1468-0297. t01-1-00150 
Bratman, M. E. (1992). Shared cooperative activity. Philos. Rev. 101, 327-341. doi: $10.2307 / 2185537$

Burton-Chellew, M. N., and West, S. A. (2013). Prosocial preferences do not explain human cooperation in public-goods games. Proc. Natl. Acad. Sci. U.S.A. 110, 216-221. doi: 10.1073/pnas.1210960110

Cannon-Bowers, J. A., and Salas, E. (2001). Reflections on shared cognition. J. Organ. Behav. 22, 195-202. doi: 10.1002/job.82

Cook, K. (Ed.) (2001). Trust in Society. New York, NY: Russell Sage Foundation.

Delgado, M. R., Frank, R. H., and Phelps, E. A. (2005). Perceptions of moral character modulate the neural systems of reward during the trust game. Nat. Neurosci. 8, 1611-1618. doi: 10.1038/nn1575

Dirks, K. T., and Ferrin, D. L. (2001). The role of trust in organizational settings. Organ. Sci. 12, 450-467. doi: 10.1287/orsc.12.4.450.10640

Dylan, B. (1985). Trust Yourself. New York, NY: Simon \& Schuster.

Fehr, E. (2009). On the economics and biology of trust. J. Eur. Econ. Assoc. 7, 235-266. doi: 10.1162/JEEA.2009.7.2-3.235

Fehr, E., and Fischbacher, U. (2004). Social norms and human cooperation. Trends Cogn. Sci. 8, 185-190. doi: 10.1016/j.tics.2004.02.007

Fehr, E., and Gächter, S. (1998). How effective are trust-and reciprocity-based incentives. Econ. Values Organ. 337-363. doi: 10.1017/CBO9781139174855.015

Fehr, E., and Gächter, S. (2000). Fairness and retaliation: The economics of reciprocity. J. Econ. Perspect. 14, 159-181. doi: 10.1257/jep.14.3.159

Fehr, E., and Rockenbach, B. (2003). Detrimental effects of sanctions on human altruism. Nature 422, 137-140. doi: 10.1038/nature01474

Fukuyama, F. (1995). Trust: The Social Virtues and the Creation of Prosperity (No. D10 301 c. 1/c. 2). New York, NY: Free press.

Gambetta, D. (ed.). (2000). "Can We Trust Trust?, Chap. 13," in Trust: Making and Breaking Cooperative Relations, Electronic Edn. (Oxford: Department of Sociology, University of Oxford), 213-237.

Guiso, L., Sapienza, P., and Zingales, L. (2006). Does culture affect economic outcomes?. J. Econ. Perspect. 20, 23-48. doi: 10.1257/jep.20.2.23

Hamilton, W. D., and Axelrod, R. (1981). The evolution of cooperation. Science 211, 1390-1396.

Hardin, R. (2001). "Conceptions and explanations of trust," in Trust in Society, ed K. S. Cook (New York, NY: Russell Sage Foundation), 3-39.

Hetherington, M. J. (1998). The political relevance of political trust. Am. Pol. Sci. Rev. 92, 791-808. doi: 10.2307/2586304

Johnson, N. D., and Mislin, A. A. (2011). Trust games: a meta-analysis. J. Econ. Psychol. 32, 865-889. doi: 10.1016/j.joep.2011.05.007

King-Casas, B., Tomlin, D., Anen, C., Camerer, C. F., Quartz, S. R., and Montague, P. R. (2005). Getting to know you: reputation and trust in a two-person economic exchange. Science 308, 78-83.

Knack, S., and Keefer, P. (1997). Does social capital have an economic payoff? A cross-country investigation. Q. J. Econ. 112, 1251-1288. doi: $10.1162 / 003355300555475$

Kosfeld, M., Heinrichs, M., Zak, P. J., Fischbacher, U., and Fehr, E. (2005). Oxytocin increases trust in humans. Nature 435, 673-676.
Kramer, R. M. (1999). Trust and distrust in organizations: emerging perspectives, enduring questions. Annu. Rev. Psychol. 50, 569-598. doi: 10.1146/ annurev.psych.50.1.569

Lewis, J. D., and Weigert, A. (1985). Trust as a social reality. Soc. Forces 63, 967-985. doi: 10.2307/2578601

Mayer, R. C., Davis, J. H., and Schoorman, F. D. (1995). An integrative model of organizational trust. Acad. Manag. Rev. 20, 709-734.

Mitkidis, P., McGraw, J. J., Roepstorff, A., and Wallot, S. (2015). Building trust: Heart rate synchrony and arousal during joint action increased by public goods game. Physiol. Behav. 149, 101-106. doi: 10.1016/j.physbeh.2015.05.033

Mitkidis, P., Sørensen, J., Nielbo, K. L., Andersen, M., and Lienard, P. (2013). Collective-goal ascription increases cooperation in humans. PLoS ONE 8:e64776. doi: 10.1371/journal.pone.0064776

Ostrom, E., and Walker, J. (1991). Communication in a commons: cooperation without external enforcement. Lab. Res. Polit. Econ. 287-322.

Putnam, R. D. (1993). The prosperous community. Am. Prospect. 4, 35-42.

Rand, D. G., Dreber, A., Ellingsen, T., Fudenberg, D., and Nowak, M. A. (2009). Positive interactions promote public cooperation. Science 325, 1272-1275. doi: $10.1126 /$ science. 1177418

Rand, D. G., and Nowak, M. A. (2013). Human cooperation. Trends Cogn. Sci. 17, 413-425. doi: 10.1016/j.tics.2013.06.003

Sellaro, R., Hommel, B., de Kwaadsteniet, E. W., van de Groep, S., and Colzato, L. S. (2014). Increasing interpersonal trust through divergent thinking. Front. Psychol. 5:561. doi: 10.3389/fpsyg.2014.00561

Slovic, P. (1993). Perceived risk, trust, and democracy. Risk Anal. 13, 675-682. doi: 10.1111/j.1539-6924.1993.tb01329.x

Wallot, S., Mitkidis, P., McGraw, J. J., and Roepstorff, A. (2016). Beyond synchrony: joint action in a complex production task reveals beneficial effects of decreased interpersonal synchrony. PLoS ONE 11:e0168306. doi: 10.1371/journal.pone.0168306

Weisel, O., and Shalvi, S. (2015). The collaborative roots of corruption. Proc. Natl. Acad. Sci. U.S.A. 112, 10651-10656. doi: 10.1073/pnas.1423035112

Williams, L. E., and Bargh, J. A. (2008). Experiencing physical warmth promotes interpersonal warmth. Science 322, 606-607. doi: 10.1126/science.1162548

Yamagishi, T., and Yamagishi, M. (1994). Trust and commitment in the United States and Japan. Motiv. Emot. 18, 129-166. doi: 10.1007/BF02249397

Conflict of Interest Statement: The authors declare that the research was conducted in the absence of any commercial or financial relationships that could be construed as a potential conflict of interest.

Copyright (C) 2017 Mitkidis, Porubanova and Roepstorff. This is an open-access article distributed under the terms of the Creative Commons Attribution License (CC BY). The use, distribution or reproduction in other forums is permitted, provided the original author(s) or licensor are credited and that the original publication in this journal is cited, in accordance with accepted academic practice. No use, distribution or reproduction is permitted which does not comply with these terms. 